\title{
CORPORATE GOVERNANCE THE JOURNEY OF INDIAN CORPORATE WORLD
}

\author{
Subha Kant Padhi \\ Professor, Xavier Institute of Management Bhubaneswar \\ Xavier Square, Jaydev Vihar, Bhubaneswar \\ Odisha, India
}

\begin{abstract}
Like many other regulations, which have been enacted to develop a control mechanism, the corporate governance rules, regulations and guidelines have come into fore to regulate, if not control, the corporate misdeeds/misdealings. Be it the boardroom fight or the $C E O$ and $C F O$ conievance or the management-auditor hand in glove story, each has lead to some corporate fraud or disruption. In this preocess, the biggest loser has been the investor, who ultimately bears the burnt of the mismanagement or deficit in governance of the corporate affairs. This is a global phenomena and India being a part of the global economy, also suffers from such deficits. There are many regulations in the international scenario. The most important ones are the OECD guidelines, SOX of USA, Cadbury Committee report of UK. In India SEBI has formulated many rules including the listing agreement under clause 49 based on the recommendations of different committees. Through this study an attempt has been made to understand how the framework has evolved over a period of time in India and how many of the large sized accounting frauds have taken place due to poor Corporate governance mechanism in place.
\end{abstract}

Keywords: Cadbury Committee, Corporate governance, India, OECD principles, SEBI.

Cite this Article: Subha Kant Padhi, Corporate Governance the Journey of Indian Corporate World, International Journal of Management, 10 (1), 2019, pp. 26-32. http://iaeme.com/Home/issue/IJM?Volume=10\&Issue=1

\section{INTRODUCTION}

In 1991, the Global economy woke up to the news that India was ready to open up its economy for global integration.

This paved the way for huge inflow of global money into the country. It also brought many money managers. The money that flew into India required good money managers and consequently came many money managers into the country. Many domestic money managers elevated them into a higher orbit. As the money was deployed by the Corporates, the top management of these corporates hired the money managers' services. The managers deployed 
some creative and advance techniques to impress the top management of the corporates, which led to many unethical practices. To control these unethical practices, a set of giudance and rules have been framed in the form of 'Corporate Governance'.

\section{CORPORATE GOVERNANCE - SOME DEFINITIONS}

One of the commonly used and widely accepted defition comes from the report of the 1992 Cadbury Committee in UK on this suject. According to this committee it is the 'system' that directs and controls the affairs of the company is the mechanism of corporate governance.

Broadly speaking corporate governance is the framework which defines the relationship among the variuos stakeholders i.e.top management, promotors, the Board, the shareholders and other external stakeholders.

The Organisation for Economic Co-operation and Development ( OECD ) in 1999 first issued a set of guideleines named as 'Principles of Corporate Governance' and later revised the same in 2003. It was finally agreed upon by the OECD member countries in April 2004.

It states "Corporate governance involves a set of relationships between a company's management, its board, its shareholders and other stakeholders. Corporate governance also provides the structure through which the objectives of the company are set, and the means of attaining those objectives and monitoring performance are determined."

\section{OECD 'PRINCIPLES OF CORPORATE GOVERNANCE'}

The main areas under this principle are summrises by OECD Observer ( 2004) as follows:

I. Ensuring the basis for an effective corporate governance framework

II. The rights of shareholders and key ownership functions

III. The equitable treatment of shareholders

IV. The role of stakeholders in corporate governance

V. Disclosure and transparency

VI. The responsibilities of the board

\section{EVOLUTION OF CORPORATES IN INDIA}

There exist many corporates in India from the pre independence era. Post-independence, many small business entities, mostly proprietory concernes, grew in size. With the growth in size, they required more persons to manage the business and consequently, the other members from the family (brother/son of the individual) joined the business. This led to the conversion of the propritory concern into partnership firms. All important decisions were taken by these family members. As their business grew further, there was a requirement of more fund, which led to the corporatisation of their business entity. This helped them to list their company in the stock exchage and invite the public at large to invest in their company with a better return than from investments in Bank deposits or gold. Depending on the prospects, many individuals and other entities invested in these corporates.

Though, legally thses corporates are separate legal entities and have separate management teams, most of the management control remained with the family members as they were occupying those important managerial positions. They always had the ability to influence the business decisions and twiked it in their favour. This resulted in the loss to other (outside) investors and many at times also led to fradulent activities. This led to the need for these corporates to be answarable to the investors, in specific, and public at large, to retain the investors' confidence in the company in which they have invested their money. 


\section{THE DEVELOPMENT OF GOVERNANCE \& LEGAL FRAMEWORK}

Keeping in mind the necessity to regulate these corporates, the Securities and Exchage Board of India was formed in 1992. SEBI issued a set of guidelines to be adhered to by these corporates to ensure the protection of the investors. However, there were many loopholes in these guideleines, which were exploited by some brokers led by Harshad Mehta and the country witnessed the biggest stock market scam including that of the UTI scam. The magnitude was so large that almost all investors lost faith in the stock market as they lost millions of rupees of their hard earned money. They Government of the time was also taken by surprise and had no immediate remedy for the same.

It was in 1998, the Confederation of Indian Industries (CII ) formed a committee under Shri Rahul Bajaj. Based on the committee's recommendations it came out with a set of guideleines names "Desirable Corporate Governance". This was the first major step in India in creating the ambience for Corporate Governance.

In year 2000, SEBI notified the Clause 49 of the Listing Agreement. This clause required every listed company to sign this agreement that was designed to address the issues of corporate governance. This was the outcome of the recommendations of the Kumaramangalam Birla Committee on Corporate Governace set up by SEBI.

Over the period of time this clause has under gone changes based on various committee recommendations. For example, the Naresh Chandra Committee had recommended the procedure to be followed for appointment of Auditors. Similarly, the Narayan Murty Committee had made recommendations regardsing quality of disclosures in financial statements and responsibility of audit committee etc.

It was the Satyam case in 2009 which shook the entire country once again. This time the Ministry of Company Affairs ( MCA) released a new set of guidelines on corporate governance named "Corporate Governance Voluntary Guidelines 2009".

In 2012, a committee headed by Adi Godrej, had made some recommendations like separate meeting of independent direcotors, whistleblower mechanism, Risk management committee etc. and SEBI has immediately incorporated the same in Clause 49.

In the meantime, the Companies Act was amended and a completely revised and revamped act came into picture in 2013. This Act also gave a lot of teeth to the Accounting Standards and guidelines issued by the 'Institute of Chartered Accountnats of India' and the 'Institute of Company Secretaries of India'. Any non adherance to these standards and guidelines while conducting the business of the company and reporting the financials of the companies is now punisable under the law.

\section{MAJOR ISSUES IN INDIA UNDER CORPORATE GOVERNANCE}

\subsection{Board Composition}

This has been a major challenge in India as most of the large size business are family owned and the board consist of relatives of the promotors. Though the Rahul Bajaj Committee and the Kumaramangalam Birla committee has harped upon the fact that the board should be independent of the family, in practice the same is not yet fully implemented. Even in a company like Infosys, the founder Mr. Narayan Murty inducted his son into the board thereby raising questions on the soundness of the corporate governance in that company.

\subsection{Independent Directors}

"How independent are the independent directors", scremed one news headline when it was found that an independent director gets a huge amount of money from the company as sitting 
fees for being a part of the Board. This puts a big question mark on the independence of such directors in the Board meetings. It has been observed that they fail to enhance the accountability as they are not able to express their opposition to any manipulation. In the Audit Committee, an independent director is supposed to ensure that the disclosures are properly made in the financial statements. The issue with an independent director is that the moment he or she expresses any dissent to the board decision, they are shown the door. Even an experienced Corporate leader like Mr. Nusli Wadia could not escape from the same.

\subsection{The Regulation}

The Companies Act, 2013 requires a board should have at least one woman director and atleast one-third of the company board should comprise of Independent Directors. As per the latest report, out of 1600 listed companies under NSE, 104 companies are yet to appoint the independent directors. The availability of Independent directors, in itself, has become a challenge for the corporates. The Act also requires the companies and the auditors to follow the GGAP and Accounting Standards pronounced by The Institute of Chartered Accountants of India and The Institute of Company Secretaries of India. However, there are many loopholes in these standards and the same is exploited by the management as well as the auditors.

\subsection{Issue of NPAs}

Bad assets continues to bug down the corporate world. The poor acquisition and investment decisions have resulted in dead assets. This is mainly due to poor corporate governance. The mounting pressure on the management to give a lucrative return to the investors so that the investors do not shy away from the company has led to accounting manipulations and cover up in the reporting of the financial statements.

\subsection{Promoters vs Management}

Most of the large size businesses in India are family run. However, over a period of time these companies have tried to become more professional by appointing outsiders as CEOs \& COOs and CFOs. This has also led to some amount of conflict between them. In recent times, the fight in TATA group and Infosys were examples of the same. It also reflected the poor corporate governance policy of these companies and also has put question mark on their succession plan.

\subsection{EXCESSIVE POWER DELEGATED TO EXECUTIVE MANAGEMENT}

In the case of Enron and Satyam, it was observed that there was almost no control on the top management. Even the auditor or the audit committee or the Board of Directors could not stop them as the top management enjoyed too much of power.

\section{LEADING ACCOUNTING FRAUDS AND ISSUE OF CORPORATE GOVERNANCE}

\subsection{Case-I Company-Waste Management, Year-1998, Country-USA}

The story - Founder Dean L. Buntrock who was also the CEO and Chairman of the company joined hands with a few more top executives of the entity and took the auditors Arthur Andersen on board. The company proposed and the audit firm certified the arrangement wherein amount of depreciation was reduced by increaseing the life of the PPE over which the 
depreciation is spread. As the life of the PPE increased, the amount of depreciation decreased, thereby resulting in a higher profit. This came to limelight with the change in CEO.

Technique used -Fictitiuos profit of $\$ 1.7$ billion by increasing the life of the PPE (consequently reducing the depreciation)

Action Taken -The audit firm was also penalised for an amount of \$7 million while the shareholders suit was settled for $\$ 457$ million. The company introduced the whistleblower concept by installing a hotline for employees.

Corporate Governance Issue -i.Issue of Board Composition, ii. Audit committee, iii. Change of auditors at regular interval

\subsection{Case II Company-Enron, Year-2001, Country-USA}

The story - Jeff Skilling, the CEO of the company along with a former CEO Ken Lay designed this fraud by not showing a substantial amount of liabilities in the financial staements. These were kept as off balance sheet items. There was an internal whistleblower, who brought it out to the open. Investors lost almost $\$ 74$ billion of their investment and thousands of employees lost their job and retirement benefits. The auditors Arthur Andersen, did not report these debts and were found involved in manipulating the accounts.

Technique used - Fictitiuos profit of $\$ 1.7$ billion reported in the financial statement

Action Taken -The punishment by the court was severe and Jeff Skilling was sent behind bars for about 24 years while former CEO Ken Lay died before the completion of the prison time. The company filed for bankruptcy. Auditors Arthur Andersen were banned forever and has to be closed down permanently.

Corporate Governance Issue -i.Issue of Board Composition, ii. Audit committee, iii. Change of auditors at regular interval

\subsection{Case III Company -WorldCom, Year -2002, Country - USA}

The story-It was a Telecommunications company with Bernie Ebbers as the CEO. He along with the CFO, manipulated the accounts by adding the revenue expenses to the assets cost, there by capitalizing revenue expenses. This led to the increase in assets value to the tune of $\$ 11$ billion. Company filed for bankrupcy. Almost 30,000 lost their jobs and \$180 billion was lost by the investors.

Technique used-Added the revenue expenses to the asset cost thereby by capitalizing same rather than putting them into the expense side of the income statement. This resulted in fictitious earnings of as much as $\$ 11$ billion.

_Action Taken-CEO Bernie Ebbers was sentensed for 25 years in prison. The CFO was dismissed. Following this scam, the Sarbanes-Oxley Act came into existence.

Corporate Governance Issue-i. Issue of Board Composition, ii. Audit committee

\subsection{Case IV Company-Tyco, Year -2002, Country -USA}

The story- The key players were the CEO Dennis Kozlowski and former CFO Mark Swartz, who misappropriated almost $\$ 150$ million and increased the revenue of the company to the tune of $\$ 500$ million. It was during an investigation by the SEC and Manhattan D.A.some grey areas of accounting practices came into light and further investigation revealed that huge amount of loans given to CEO Dennis Kozlowski were waived.

Technique used-Company fund was transferred in the disguise of executive bonues and benefits without approval and there were fraudulent stock sales 
Action Taken-The court awarded a punishment of almost 25 years in prison for Kozlowski and Swartz. The court case decided in favour of the investors and Tyco ended up paying $\$ 2.92$ billion as compensation to investors.

Corporate Governance Issue-i.Issue of Board Composition, ii. Audit committee,

\subsection{Case V Company-Satyam, Year -2009, Country -INDIA}

The story-Founded by Shri Ramalinga Raju. The accounts were falsified to increase the rvenue, cash balance 50 billion rupees. Shri Ramalinga Raju disclosed about the accounting fraud to the Board through a letter.

Technique used-Forged accounts to show higher revenue to the tune of $\$ 1.5$ billion.

Action Taken-Mr. Raju and his brother were arrested and put in jail pending investigation. However, they were released as no chargesheet was filed by Central Bureau of Investigation on time. The auditors, though intially escaped without any penalty, are now being questioned by SEBI.

Corporate Governance Issue-i.Issue of Board Composition, ii. Audit committee iii. Change of auditors at regular interval

\subsection{Case VI Company-Ricoh India, Year -2018, Country -INDIA}

The story-The company reported a loss of Rs.11, 180 million as the books of account did not reflect a true and fair view during FY 2015-16. Ricoh India on 19 July 2016 admitted to the fact of possible doctoring of its books of accounts. The Japanese promoter entity Ricoh Co. Ltd proposed to recapitalise the firm for the loss.

Technique used-Falsification of Accounts

Action Taken-SEBI (The Securities and Exchange Board of India) has barred top managerial personnel (six of them ) of the company from any type of dealings with the stock market till further order. SEBI is now investigating the case through its own experts rather than deploying any external accounting firm. It has expressed the apprehension that the magnitute of this fraud could be one of the largest since the Satyam scam.

Corporate Governance Issue- i.Issue of Board Composition, ii. Audit committee

\section{INTERESTING OBSERVATIONS FROM SOME CORPORATE FRAUDS ACROSS THE GLOBE}

Looking at the various accounting frauds, the following can be summrised (a bird's eye view of the failure in corporate governance that added fuel to such frauds)

i. In all the cases the CEO and/or the CFO were involved.

ii. These corporates were audited by one of top 5 auditing firms of the world but still the fraud took place.

iii. Most of the large size frauds have happened in USA, despite having a strong regulation.

iv. Except for the audit firm Aurther \& Anderson ( completely shut down/disbanded), no other firm has been severly punished.

v. In almost all cases, the auditors and top management were hand in glove to help such fraud take place.

\section{INDIA'S POSITION IN CORPORATE GOVERNANCE}

Despite having seen some scams taking place, India still stands tall as far as the protection of the interest of the minority shareholders are concerned. The World Bank Report 2018 on Ease 
of Doing Business as put India at $4^{\text {th }}$ position in this respect which in itself it a great achievement and can be easily attributed to the strigent regulatory measures being taken by SEBI and the government.

\section{WAY FORWARD}

Like any other issue that affects or could possibly affect the corporate world, corporate governance issue, is affecting at present and will affect in future, almost every corporate, whether listed or not. Even for a company like Infosys, where the Corporate Governance is given the utmost importance, this has raised many eyebrows when the executive compensation was given for a golden handshake.

Though there is no watertight system for corporate governance, the stringent implementation of the guidelines would go a long way in ensuring a good coprporate governance mechanism in the listed companies.

The recommendations of the high powered Kotak Committee, if implemented in sincerety, will also strongly help in improving the Corporate Governace in companies in India.

\section{REFERENCES}

[1]Cadbury Committee Report, 27 may 1992

[2] Principles of Corporate Governance, OECD,1999

[3] Confederation of Indian Industry, Desirable Corporate Governance, March 1998

[4] Sarbanes Oxley Act of 2002

[5]Department of Company Affairs, Report Corporate Excellence through Governance, 2000

[6] Kumar Mangalam Birla Committee on corporate Governance, March 2000

[7] Securities and Exchange Board of India (2002) Report on SEBI Committee on Corporate Governance (under the chairmanship of Shri N R Narayanamurthy)

[8]Report of the CII Taskforce on Corporate Governance Chaired by Mr. Naresh Chandra, November 2009

[9][9] Ministry of Corporate Affairs, Government of India. Corporate Governance Voluntary Guidelines 2009,

[10] Securities and Exchange Board of India Clause 49 of listing agreement.

[11] Adi Godrej Committee, 2012

[12] Kotak Committee, 2018

[13] G.N.Bajpai, The essentials of corporate governance ( Sage India, 2017)

[14] Neville Bain, David Band, Winning ways through corporate governance ( Macmillan Press Ltd. London, 1996)

[15] https://www.sebi.gov.in/reports/reports/oct-2017/report-of-the-committee-on-corporategovernance_36177.html

[16] https://www.sebi.gov.in/media/press-releases/mar-2018/sebi-board-meeting_38473.html 